ROCZNIKI TEOLOGICZNE

Tom LXVI, zeszyt 5 - 2019

DOI: http://dx.doi.org/10.18290/rt.2019.66.5-2

STANISŁAW T. ZARZYCKI SAC

\title{
DUCHOWA MISJA UNIWERSYTETU KATOLICKIEGO WEDŁUG ŚW. JANA PAWŁA II
}

\author{
SPIRITUAL MISSION OF THE CATHOLIC UNIVERSITY \\ ACCORDING TO ST. JOHN PAUL II
}

\begin{abstract}
A b s t r a c t. The University as a "unique center of creative work and radiation of knowledge, serving the good of humanity," although it grows out of the tradition shaped by the Church, in contemporary globalized societies it is in crisis because it was largely dependent on utilitarian thinking and mercantilist factors and transformed into a model serving the interests of the social and economic evolution of these societies. The article is an attempt to comprehensively define the mission of a Catholic university on the basis of the Ex Corde Ecclesiae Constitution of John Paul II and his speeches to the university world and cultural environments. This mission consists in: 1) searching for "the whole truth about nature, man and God" referring to faith and reason and their ability to derive truth from two sources: revelation and created reality; 2) creating a community based on truth, one vision of human dignity, Christian values and upbringing into Christian and human maturity; 3) preparing students to realize their vocation in the Church and in the world, including participation in the evangelization of cultures as well as building culture and civilization worthy of man.
\end{abstract}

Key words: Catholic University; mission; truth; man; community; evangelization; good of socjety.

\section{WPROWADZENIE}

Św. Jan Paweł II podczas swych pielgrzymek, podejmowanych do wiernych wielu krajów świata, wielokrotnie spotykał się z ludźmi nauki, środowiskami uniwersyteckimi i dawał wyraz przekonaniu, że ,nauka jest darem pochodzącym z wysoka i zarazem zdobyczą niestrudzonego ducha, który poszukuje i znajduje, wyjaśnia i porządkuje" poznanie rzeczywistości. Wskazywał też, że „nauka prowadzi do wyzwolenia i wywyższenia człowie-

Dr hab. StanisŁaw T. Zarzycki SAC, prof. KUL - Katedra Historii Duchowości w Instytucie Nauk Teologicznych KUL; adres do korespondencji: Al. Racławickie 14; $20-950$ Lublin; e-mail: szarzycki@kul.pl 
ka"1. Z otrzymanym od Boga darem, talentem człowiek nauki powinien współdziałać pomnażając go dla dobra własnego i dla dobra społeczeństwa, narodu i ludzkości. Szczególnym miejscem tego współdziałania jest uniwersytet.

„Narodzony z serca Kościoła uniwersytet katolicki stanowi część tradycji sięgającej samych początków instytucji uniwersytetu i jawi się niezmiennie jako jedyny w swoim rodzaju ośrodek twórczej pracy i promieniowania wiedzy, służący dobru ludzkości" ${ }^{2}$ - pisał Papież. Twierdził, że jest on ,jednym z najlepszych instrumentów, jakie Kościół ofiaruje naszej epoce, poszukującej pewności i mądrości" ${ }^{3}$. Do osób kierujących uniwersytetami katolickimi i do wspólnot akademickich Ojciec Święty skierował dwie konstytucje: Sapientia christiana o uniwersytetach $i$ wydziałach kościelnych oraz Ex Corde Ecclesiae o uniwersytetach katolickich ${ }^{4}$. Celem pierwszej konstytucji było głównie określenie ogólnych praw i norm, którymi mają się kierować wydziały kościelne zakładane przez Stolicę Apostolską, by „odpowiadały postulatom bieżącej epoki” i mogły realizować właściwe im zadania. Celem zaś drugiej, stanowiącej o wiele bogatszy merytorycznie dokument, jest „skłonienie do takich działań, dzięki którym zaistnieje 'jakby publiczna, stała i powszechna obecność myśli chrześcijańskiej w całym wysiłku skierowanym ku rozwijaniu wyższej kultury, a wychowankowie tych instytutów będą kształtować się na ludzi naprawdę odznaczających się w nauce, przygotowanych do spełnienia poważnych obowiązków społecznych oraz na świadków wiary w świecie", 5 .

Papież określał niejednokrotnie rolę uniwersytetu „misją”, podkreślając, iż „wydaje się [ona] coraz bardziej potrzebna w sytuacji spotkania Kościoła z rozwojem nauki i z kulturami naszych czasów"6. Na czym polega owa misja uniwersytetu katolickiego dzisiaj według Jana Pawła II i jaka jest jej specyfika? Czym różni się ona od oddziaływania uniwersytetu o paradygmacie pozytywistycznym czy postmodernistycznym? A może jest zwykłym odwzorowaniem misji uniwersytetu tradycyjnego, klasycznego? ${ }^{7}$

\footnotetext{
${ }^{1}$ Jan PAWE⿺ II, Silmy się dobrze myśleć. Spotkanie z przedstawicielami świata nauki i kultury. Triest 2 V 1992, OsRom 7(1992), s. 16.

2 JAN PAwE⿺ II, Konstytucja apostolska Ex Corde Ecclesiae o uniwersytetach katolickich (15 kwietnia 1979), 1, w: TENŻE, Dzieła zebrane, t. IV, Kraków 2007, s. 86.

${ }^{3}$ Tamże, nr 10.

${ }^{4}$ Jan PaWee II, Konstytucja apostolska Sapientia christiana o uniwersytetach $i$ wydziałach katolickich (15 sierpnia 1990), w: TENŻE, Dzieła zebrane, t. IV, s. 15-31.

${ }^{5}$ Tamże, nr 9.

${ }^{6}$ Tamże, nr 10; TENZE, Ex Corde Ecclesiae, 25.

${ }^{7} \mathrm{~W}$ historii można wyróżnić trzy główne paradygmaty uniwersytetu różniące się od siebie przedmiotem zainteresowań, stosunkiem do prawdy i postawą wobec tradycji uniwersyteckiej.
} 


\section{MISJA POSZUKIWANIA „CAŁEJ PRAWDY O NATURZE, O CZŁOWIEKU I O BOGU"}

„Powołaniem każdego uniwersytetu jest służba prawdzie: jej odkrywanie i przekazywanie innym”8. „Uniwersytet katolicki dzieli wraz ze wszystkimi innymi uniwersytetami [...] radość poszukiwania prawdy we wszystkich dziedzinach wiedzy, odkrywanie jej i głoszenie"9. Poszukiwaniu, a zwłaszcza znajdowaniu prawdy będącej wartością duchową - zdaniem Augustyna - towarzyszy radość (gaudium de veritate), a nawet szczęście, polega ono w istocie na „radowaniu się prawdą”, którą jest Bóg ${ }^{10}$. Przyjmując to augustyńskie spostrzeżenie o udziale w prawdzie i jej duchowych owocach tych, którzy tworzą uniwersytet katolicki i w nim poszukują prawdy, Papież upatruje szczególne zadania uniwersytetu katolickiego w tym, że w pracy intelektualnej będzie on łączyć dwa porządki: 1) poszukiwanie prawdy i (2) „pewność, że zna się źródło prawdy”" Papież mówi o „pewności” wynikającej ze „źródła prawdy”, czyli z Boga, z Chrystusa, który określił siebie jako prawdę (J 14,6) i, za Augustynem, wskazuje na elementarne powiązanie i ukierunkowanie bytu ludzkiego na prawdę Bożą i na samego Boga ${ }^{12}$, dając do zrozumienia, że Bóg jako Prawda jest u początku wszystkich ludzkich poszukiwań prawdy i zarazem ich kresem ${ }^{13}$. „Pragnienie prawdy jest tak głęboko zakorzenione w sercu człowieka, że gdyby musiał się go wyrzec, prowadziłoby to do kryzysu egzystencjalnego"14.

Pytanie o prawdę poszukiwaną w uniwersytecie, w myśli Jana Pawła II, łączy się ściśle z człowiekiem, który o nią pyta i w jej świetle odkrywa swą wielkość i przeznaczenie. „Człowiek ma żywą świadomość, iż prawda jest poza i „ponad” nim samym. Człowiek prawdy nie tworzy, ale ona sama się

S. WiElgus, O nowym paradygmacie uniwersytetu z okazji inauguracji osiemdziesiatego roku akademickiego w Katolickim Uniwersytecie Lubelskim, „Przegląd Uniwersytecki”. Dodatek Specjalny, Lublin 1997, s. 12.

${ }^{8}$ JAN PAWE⿺ II, Przemówienie wygłoszone z okazji sześćsetlecia Wydziału Teologicznego Uniwersytetu Jagiellońskiego, Kraków, 8 czerwca 1997 r., w: TEnżE, Dzieła zebrane, t. IX, Kraków 2007, s. 744.

${ }^{9}$ Jan PAWEl II, Ex Corde Ecclesiae, 1.

${ }^{10}$ Św. Augustyn, Wyznania, X, 23, thum. Z. Kubiak, Warszawa 1992, s. 309.

${ }^{11}$ Jan Pawel II, Ex Corde Ecclesiae, 1.

${ }^{12}$ Św. Augustyn, Wyznania, I, 1,

${ }^{13}$ Jan PaweŁ II, Prawdy o człowieku nie można oddzielić od prawdy o Bogu. Przemówienie do profesorów i studentów Instytutu Katolickiego. Paryż, 1 czerwca 1980, w: TENŻE, Wiara i kultura, oprac. M. Radwan SCJ i in., Rzym-Lublin 1988, s. 46.

${ }^{14}$ JAN PAWE⿺ II, Encyklika Fides et ratio o relacjach między wiara a rozumem, 29. 
przed nim odsłania, gdy jej wytrwale szuka" ${ }^{15}$. Chodzi tu nie o jakąś cząstkową prawdę, ale o prawdę pochodzącą z samego źródła prawdy transcendentnego w stosunku do świadomości człowieka. Z drugiej strony bez człowieka, jako osobowego podmiotu, nie ma prawdy jako obiektywnej wartości dla innych, gdyż to człowiek, zgłębiając prawdę, odnajduje jej obiektywny sens i chroni ją przed zniekształceniem. Dla metodologii poznania prawdy ważne jest to, co papież mówi o różnych jej formach: „Najliczniejsze są te, które opierają się na dowodach bezpośrednio dostępnych lub które można potwierdzić eksperymentalnie. Jest to rząd prawd występujących w życiu codziennym i w sferze badań naukowych. Na innej płaszczyźnie usytuowane są prawdy natury filozoficznej, do których człowiek dociera dzięki zdolności spekulatywnej rozumu. Istnieją wreszcie prawdy religijne" ${ }^{\prime 16}$, czyli objawione przez Jezusa Chrystusa o Bogu. Ukazując, iż religijność jest „najwznioślejszym wyrazem osoby ludzkiej, gdyż jest szczytem jej rozumnej natury"17, Jan Paweł II uznaje prawdę religijną za prawdę najpełniejszą. Wyszczególnionych trzech form prawdy (objawionej, filozoficznej i naukowej) nie należy postrzegać rozłącznie, ale należy widzieć jej ,jedność”, która jest „podstawowym postulatem ludzkiego rozumu wyrażonym już w zasadzie niesprzeczności. Ta jedność prawdy naturalnej i objawionej znajduje swe żywe i osobowe wcielenie w Chrystusie" 18 . Jako przykład człowieka poszukującego prawdy i dostrzegającego ją w wymiarze uniwersalnym, obiektywnym i transcendentnym Jan Paweł II podaje św. Tomasza z Akwinu, nazywając go ,apostołem prawdy”.

W jaki sposób uniwersytet katolicki winien prowadzić badania naukowe, aby były one poszukiwaniem prawdy o naturze i nie odrywały się od wyższych form prawdy, ale były z nimi powiązane?

Odpowiedź na to pytanie domaga się uwzględnienia rzeczywistej i pełnej oceny wartości poznania naukowego przez człowieka współczesnego. Poznanie to jest powszechnie doceniane ze względu na postęp techniczny i informatyczny, do którego doprowadziło czyniąc łatwiejszymi warunki życia człowieka na ziemi. $Z$ tej racji niejednokrotnie pojmuje się naukę jedynie w sposób techniczny, nie dostrzegając jej wyższej roli i nie widząc niezamierzonych negatywnych skutków rozwoju cywilizacyjnego, np. zniszczenia przyrody. Najbardziej szkodliwym skutkiem kultury naznaczonej techniką

\footnotetext{
${ }^{15}$ Jan PAWE⿺ II, Przemówienie wygloszone z okazji sześśsetlecia Wydziału Teologicznego Uniwersytetu Jagiellońskiego, Kraków, 8 czerwca 1997 r., w: TeNŻE, Dzieła zebrane, t. IX, s. 744.

${ }^{16}$ JAN PAWEL II, Fides et ratio, 30.

17 JAN PAWE⿺ II, List do Rodzin Gratissimam sanae (2. luty 1994), 10.

${ }^{18}$ JAN PAWEL II, Fides et ratio, 34.
} 
jest manipulowanie człowiekiem dla uzyskania celów ekonomicznych i politycznych. „Jeśli nauka będzie pojmowana 'technicznie' - pisze Jan Paweł II - może stać się poszukiwaniem takich metod, które prowadzą do oczekiwanych skutków technicznych. Za 'osiągnięcia poznawcze' uzna się wtedy to, co służy oczekiwanemu skutkowi. Świat otwierający się przed nauką staje się jedynie kompleksem fenomenów poddających się wpływowi, jej przedmiotem - funkcjonalne współzależności badane jedynie w perspektywie ich funkcjonalności" ${ }^{19}$. W tym przypadku nauka zostaje zredukowana do bycia jedynie „funkcją” czegoś. Jan Paweł II twierdzi, że to funkcjonalistyczne rozumienie nauki przeniknęło do wszystkich dziedzin kultury i ma wpływ na dziedzinę wartości i norm, a także na postawę duchową człowieka ${ }^{20}$. Ulega ona widocznemu osłabieniu, gdyż człowiek zachwycony osiągnięciami technicznymi zwracającymi go na zewnątrz siebie, zapomina o swym wnętrzu i o prawdziwym źródle duchowym swej mocy i swego rozwoju duchowego. Sytuacja ta wskazuje na granice nauki. Pomijając to, iż nie jest ona w stanie wyjaśnić wszystkiego o rzeczywistości, np. początku świata i że opierając się na danych skończonych, powinna uznać swą bezradność wobec tego, co nieskończone, co jest tajemnicą, nauka matematyczno-przyrodnicza nie jest w stanie rozwikłać problemu człowieka, gdyż rozpatruje go jedynie jako część przyrody, cząstkowo i nie może wyrokować o nim nie popadając w błąd brania części poznania za całość ${ }^{21}$. Nie jest w stanie udzielić odpowiedzi na wielkie pytania, np. o sens życia ludzkiego. Jan Paweł II wskazuje, że funkcjonalne rozumienie nauki, wywiedzione z nauk matematyczno-przyrodniczych, jest rozumieniem uproszczonym, nieuwzględniającym tego kim jest człowiek jako istota cechująca się osobową godnością, która winna być respektowana i powinna służyć jako kryterium oceny kulturowego zastosowania wiedzy naukowo-technicznej ${ }^{22}$.

W Przemówieniu na forum rektorów uniwersytetów europejskich Jan Paweł II podał zasmucającą diagnozę curriculum współczesnego uniwersytetu na starym kontynencie, które „zdaje się pozostawać często niezdecydowane pomiędzy formacją typu podstawowego a specjalizacją wiedzy, z konieczności coraz bardziej rozdrobnioną”. Stwierdził, iż „postępująca orientacja uniwersytetu ku produkcji przemysłowej i ku sektorowi usług uśmierciła studia i badania humanistyczne, ekonomicznie nieproduktywne i obce logice rynku.

\footnotetext{
${ }^{19}$ JAN PAWEE II, Więź myślenia naukowego z wiara warunkiem poszukiwania prawdy. Przemówienie do naukowców i studentów. Kolonia, 15 listopada 1980, w: TenżE, Wiara i kultura, s. 78-79.

${ }^{20}$ Tamże, s. 79.

${ }^{21}$ E. OzOROwSKI, Nauka a pytania graniczne, „Rocznik Teologii Katolickiej” 7(2007), s. 8.

22 JAN PAWEŁ II, Więź myślenia naukowego z wiara warunkiem poszukiwania prawdy, s. 81.
} 
Uniwersytet jest postrzegany jako mocno zredukowany w swojej funkcji pamięci przeszłości, kuźni ducha, pola ćwiczeń w badaniu tego, co piękne, metafizyczne, prawdziwe"23. Kryzys uniwersytetu, o którym mówi Papież, polega na rozdźwięku pomiędzy realizacją jego podstawowej formacji na poziomie studiów i badań humanistycznych „uśmierconych" na skutek zbytniego ukierunkowania uniwersytetu na praxis, na specjalizację wiedzy praktycznej i na interesy ekonomiczne. Jakie są przyczyny takiego stanu rzeczy? U ich podstaw jest „inne” myślenie o uniwersytecie i jego roli w społeczeństwie współczesnym, myślenie pozytywistyczne pomijające wartość człowieka w jego integralności, tzn. w sferze wartości duchowych i religijnych a ograniczające się do wymiaru immanentnego, materialnego i utylitarnego.

Papież podkreśla, że poszukiwanie prawdy, jej odkrywanie i przekazywanie innym - będące podstawową misją uniwersytetu - ,potrzebuje [...] swoistej transcendencji właściwej uniwersytetom”, gdyż „nawet wówczas, gdy dotyczy ograniczonej rzeczywistości świata czy człowieka, nigdy się nie kończy, zawsze odsyła ku czemuś, co jest ponad bezpośrednim przedmiotem badań, ku pytaniom otwierającym dostęp do Tajemnicy" ${ }^{24}$. To odniesienie do transcendencji, do Boga było obecne w badaniach i w nauczaniu uniwersyteckim od początku, gdyż w pierwszych uniwersytetach powstających zazwyczaj ze szkół katedralnych (Bolonia, Paryż, Oksford, Orlean). Teologia, obok Prawa, Medycyny i Sztuk była pierwszym z czterech wydziałów nau$\mathrm{ki}^{25}$ poświęconej problematyce specyficznie ludzkiej, humanistycznej i przetrwała w nich przez wieki, aż do czasu, gdy przyjęto inną koncepcję nauki ${ }^{26}$, koncepcję związaną z wytwarzaniem coraz doskonalszych narzędzi i budowaniem cywilizacji materialnej, konsumpcyjnej. Można powiedzieć, że dopóki istniała owa pierwotna koncepcja, wszystkie uniwersytety miały charakter katolicki, choć nie zawierały przymiotnika „katolicki” w swej nazwie. Mówiąc o uniwersytecie „zredukowanym w swojej funkcji pamięci przeszłości, kuźni ducha, pola ćwiczeń w badaniu tego co piękne, metafizyczne, prawdziwe”, Papież ma na myśli długą tradycję humanistyczną i religijną,

${ }^{23}$ Rzym, 19 kwietnia 1991, w: S. Sowiński, R. ZENDERowski, Europa droga Kościoła. Jan Pawet II o Europie i europejskości, Wrocław 2003, s. 245.

${ }^{24}$ Jan PaWet II, Przemówienie wygłoszone z okazji sześćsetlecia Wydziału Teologicznego Uniwersytetu Jagiellońskiego, s. 744.

${ }^{25}$ E. GILson, Uniwersytety i scholastyka, w: Zrozumieć Średniowiecze, wybór i oprac. R. Mazurkiewicz, Tarnów 1997, s. 222.

${ }^{26}$ Symbolicznie za datę powstania nowożytnej nauki uznaje się najczęściej rok 1687, w którym ukazało się drugie wydanie Principiów Newtona zawierających metodę badań zastosowaną w naukach przyrodniczych. J. ŻYCIŃSKI, Inspiracje chrześcijańskie w powstaniu nauki nowożyt$n e j$, Lublin 2000, s. 7. 
która w ostatnich dziesięcioleciach została w wielu uniwersytetach „uśmiercona" lub poważnie zredukowana. Bez studium filozofii klasycznej niemożliwe jest poszukiwanie i odkrywanie prawdy uniwersalnej, obiektywnej i transcendentnej, bez studium zaś teologii, odwołującej się do źródeł objawienia, nie jest możliwe zrozumienie sensu życia ludzkiego w aspekcie zbawienia i naświetlenie podstawowego doświadczenia ludzkiego (cierpienie, choroba, śmierć), które jest udziałem każdego człowieka.

„Uniwersytet katolicki jest miejscem, w którym naukowcy, posługując się metodami właściwymi każdej dyscyplinie naukowej, zgłębiają rzeczywistość, przyczyniając się w ten sposób do wzbogacenia skarbca ludzkiej wiedzy"27. Zgłębiając rzeczywistość starają się, każdy z właściwego mu punktu widzenia, dostrzec najbardziej palące problemy swego czasu i przez swoje badania przyczyniać się do ich rozwiązania. Studium każdej dyscypliny winno skłaniać profesora i studenta do dialogu z przedstawicielami innych dyscyplin, którego skutkiem jest zawsze wzajemne wzbogacenie. Postulat, a nawet konieczność dialogu między naukowcami a także naukowcami i studentami są podyktowane najpierw dostrzegalną fragmentaryzacją wiedzy. Każda dyscyplina $\mathrm{w}$ ramach swego przedmiotu materialnego i formalnego i za pomocą metod jej właściwych stara się zgłębiać rzeczywistość nie wykraczając poza ten przedmiot. Taka specjalizacja, choć jest dziś konieczna, ma ten minus, że oddala naukowców od siebie. Według Jana Pawła II, „wycinkowość wiedzy wiąże się z częściową wizją prawdy i prowadzi do fragmentaryzacji sensu, a przez to uniemożliwia człowiekowi osiągnięcie wewnętrznej jedności" ${ }^{28}$. Konieczne jest więc wykraczanie poza swój przedmiot badań i powiązanie go z szerszą perspektywą poznawczą. Doświadczenie pokazuje, że żadne poznanie szczegółowe nie może się rozwijać w izolacji od innych zakresów wiedzy, gdyż podmiot poznający jakoś w nich uczestniczy. Stąd też bardzo potrzebny jest dialog naukowy w murach uczelni. Według J. Tarnowskiego, dialog prowadzony na płaszczyźnie intelektualnej polega na „sposobie komunikowania się [...], w trakcie którego oba podmioty dążą do wzajemnego zrozumienia, zbliżenia i współdziałania" ${ }^{29}$. Dialog, nawiązany na płaszczyźnie poznawczej, umożliwia współpracę z drugą osobą.

Według Konstytucji Ex Corde Ecclesiae badania naukowe w uniwersytecie katolickim winny zmierzać do integracji wiedzy ${ }^{30}$, co zakłada powiązanie

${ }^{27}$ JAN PAWEL II, Ex Corde Ecclesiae, 15.

${ }^{28}$ JAN PAWEL II, Fides et ratio, 85.

${ }^{29}$ E. OKOŃSKA, Uniwersytet jako szkoła dialogu w spoleczeństwie obywatelskim, „Studia Bydgoskie" 1(2007), s. 157.

${ }^{30}$ Jan PaWel II, Ex Corde Ecclesiae, 15. 
prawdy, także tej o naturze rzeczy z dobrem i uchwycenie istniejących między nimi relacji ${ }^{31}$ oraz ich aplikację $\mathrm{w}$ życiu indywidualnym i społecznym. Według Jana Pawła II „nauki stosowane winny sprzymierzyć się z sumieniem, tak aby w trójczłonie: nauka-technika-sumienie służono sprawie prawdziwego dobra człowieka" [...], wartości technologii wywodzące się z nauk ścisłych należy zharmonizować $\mathrm{z}$ wartościami sumienia ${ }^{32} \mathrm{i}$ im je podporządkować, by służyły dobru człowieka i społeczeństwa a nie jedynie powierzchownym potrzebom ludzkim. Gdy chodzi o poznawanie prawdy o człowie$\mathrm{ku}$, konieczne jest uwzględnienie także prawd duchowych i moralnych oraz wartości z których się one wywodzą. Za podstawową prawdę należy przyjąć tę, że życie człowieka ma sens, który urzeczywistnia się zarówno w relacji do innych, jak i do Boga ${ }^{33}$. W tym przypadku konieczne jest wykroczenie metodologiczne poza płaszczyznę czysto przyrodniczą i rozpatrywanie życia człowieka w świetle wiary i objawienia oraz zawartego w nim planu Bożego względem jednostki i ludzkości. Badania i odkrycia, dokonywane w każdej z dyscyplin nauki zgłębianej i przekazywanej w uniwersytecie, wnoszą cenny wkład w rozwój nauki oraz w życie osób i całego społeczeństwa. Ich wartość dla człowieka i jego realizacji uwzględniającej jego godność i powołanie pomaga określić tym dyscyplinom teologia, która „ukazuje im perspektywę i nadaje kierunek" duchowej realizacji wykraczający poza ich własne metodologie ${ }^{34}$.

Badanie podejmowane zwłaszcza w płaszczyźnie antropologicznej, zakładające stosowanie wielu metodologii, łączy się z koniecznością podjęcia dia$\operatorname{logu}$ wiary z rozumem. Temu zagadnieniu Jan Paweł II poświęcił encyklikę Fides et ratio, w której w kwestii obecnego stanu tej relacji zauważył, że „domaga się rozeznania, ponieważ zarówno rozum, jak i wiara zostały

${ }^{31}$ Te zagadnienia poruszał kard. Wojtyła w swych wykładach o człowieku i moralności w Katolickim Uniwersytecie Lubelskim. Rozpatrując je w filozofii św. Tomasza, pisał: „Prawda i dobro łączą się wzajemnie, prawda bowiem jest pewnym dobrem - w przeciwnym razie nie stanowiłaby przedmiotu dążeń i wysiłków, dobro zaś jest pewną prawdą - w przeciwnym razie nie byłoby poznawalne. Dzięki temu prawda może stanowić przedmiot pożądania, tak jest u każdego, kto chce poznać prawdę, z drugiej strony zaś dobro jako przedmiot działania stanowi przedmiot poznania ze strony rozumu praktycznego, a więc zostaje ujęte jako prawda (sub ratione veri)". K. WoJTYŁA, Wykłady lubelskie. Człowiek i moralność, 3, red. T. Styczeń i in., Lublin 1986, s. 130.

${ }^{32}$ JAN PAwE⿺ II, Zharmonizować wartości technologii z wartościami sumienia. Przemówienie w Europejskim Centrum Badan Jadrowych. Genewa, 15 czerwca 1982, w: TenŻE, Wiara i kultura, s. 158.

${ }^{33}$ Jan PaweŁ II, Umitowanie prawdy źródtem poszukiwania. Przemówienie do świata uniwersyteckiego. Kinshasa, 4 maja 1980, w: TENŻE, Wiara i kultura, s. 39.

${ }^{34}$ Jan Pawel II, Ex Corde Ecclesiae, 19. 
zubożone i osłabione w swych wzajemnych odniesieniach. Rozum, pozbawiony wsparcia ze strony Objawienia, podążał bocznymi drogami, na których istniało ryzyko zagubienia jego ostatecznego celu. Wiara, pozbawiona oparcia w rozumie, skupiła się bardziej na uczuciach i przeżyciach, co stwarza zagrożenie, że przestanie być propozycją uniwersalną"35. Rozum został osłabiony, zwłaszcza od XIX w., gdy najpierw ograniczył się do scjentyzmu, pozytywizmu logicznego i zakresu niewiary, a w XX w. do postmodernistycznego nihilizmu negującego kryteria prawdy teoretycznej i aksjologicz$n^{j 36}$. Nihilizm i zagubienie, jakich doświadcza człowiek w obecnej kondycji, przejawiają się w „kryzysie sensu” życia tym bardziej tragicznym, że niejednokrotnie nieuświadomionym, z powodu zbytniego pogrążenia się człowieka w sferze doczesnej.

Dostrzegając kryzys sensu nauki i różne przejawy ograniczania jej wolności, Kościół broni wartości rozumu i nauki - w ramach całościowej, otwartej na Boga wizji człowieka - i przysługującej im wolności jako warunku rozwoju naukowego i technologicznego. Papież przypomina o wartości filozofii o zasięgu metafizycznym, zdolnej wyjść poza dane doświadczenia ku temu, co ostateczne, absolutne i mogącej „znaleźć naturalny fundament tegoż sensu, którym jest religijność wpisana w naturę każdego człowieka"37. Może ona spełnić funkcję mediacyjną pomiędzy rozumem a wiarą, pomiędzy naukami a teologią, co wymaga prowadzenia cierpliwego dialogu, w trakcie którego należy przezwyciężać z jednej strony radykalny racjonalizm, z drugiej zaś fideizm ${ }^{38}$. Wkład teologii do owego dialogu z niewierzącymi winien polegać na ukazywaniu wiary w możliwość większego poznania prawdy zawartej w Objawieniu i kierowaniu refleksji ku Bogu żywemu i Jego zamysłowi zbawienia wszystkich w Jezusie Chrystusie $(1 \mathrm{Tm} 2,4)$.

Wiara, pozbawiona oparcia w rozumie, może ulec pokusie duchowości skupionej jedynie na wewnętrznych przeżyciach nie będących odpowiedzią na miłość Bożą objawioną w tajemnicy zbawczego Wcielenia. Oto dlaczego Papież poleca dążenie do syntezy wiary i rozumu na poziomie badań i wykształcenia poprzez stosowanie zasady fides querens intellectum i zarazem przez dążenie do dojrzałości w wierze. Dialog uniwersytecki w tym względzie winien być prowadzony tak, „by można dostrzec, że wiara i rozum

\footnotetext{
${ }^{35} \mathrm{Nr} 48$.

${ }^{36}$ J. J. GURrido, Misja chrześcijanina w czasach kryzysu kultury, w: Postmodernizm, „Communio. Międzynarodowy Przegląd Teologiczny” 14(1994), 6, s. 76.

${ }^{37}$ JAN PAWEL II, Fides et ratio, 81.

${ }^{38}$ D. LAmBert, Ryzykowne spotkanie teologii z nauka, tłum. P. Korycińska, Kraków 2018, s. 259-266.
} 
spotykają się w jedynej prawdzie" ${ }^{39}$, na co wskazywał już Sobór, gdy nauczał, że te dwa porządki spraw, widzialnych i niewidzialnych wywodzą się od tego samego Boga ${ }^{40}$.

\section{TWORZENIE WSPÓLNOTY I WYCHOWANIE DO DOJRZAŁOŚCI CHRZEŚCIJAŃSKIEJ I LUDZKIEJ}

Misja uniwersytetu katolickiego nie ogranicza się jedynie do badań naukowych i przekazywania wiedzy, kształcenia, ale obejmuje integralną formację osób, które w środowisku akademickim są powołane do aktywnego uczestnictwa w życiu społeczności i Kościoła ${ }^{41}$. Jan Paweł II, jako profesor Katolickiego Uniwersytetu Lubelskiego, mówi o tej misji odwołując się do uroczystego określenia nadawanego dawniej uniwersytetom: Alma Mater, i wskazuje na jego głęboki sens: „Mater - matka, to ta, która rodzi i która wychowuje, kształci. Uniwersytet ma w sobie podobieństwo do matki, [jakieś macierzyństwo]. Podobny jest do niej przez troskę macierzyńską. Ta troska jest natury duchowej; rodzenie dusz do wiedzy, do mądrości, kształtowanie umysłów i serc. Jest to wkład nieporównywalny z niczym" ${ }^{42}$. Troskę tę przejawiają przede wszystkim profesorowie, mistrzowie, koryfeusze nauki, którzy mają za zadanie wprowadzać studentów w poznanie rzeczywistości świata i w tajniki człowieczeństwa. Jak wcześniej zauważono, obecna nauka oddzielona od refleksji metafizycznej i zredukowana pod względem humanistycznym została sprowadzona do siły napędowej społeczeństwa przemysłowego, a uniwersytet $\mathrm{w}$ dużej mierze został uzależniony od myślenia utylitarystycznego i od czynników merkantylistycznych. Forsowana profesjonalizacja motywowana koniecznością przygotowania studentów do lepszego startu na rynku pracy zapewnia w wielu uniwersytetach jedynie formację

\footnotetext{
${ }^{39}$ JaN PAWEL II, Ex Corde Ecclesiae, 17.

${ }^{40}$ Gaudium et spes, 36: „Ideo, inquisitio methodica in omnibus disciplinis, si modo vere scientifico et iuxta normas morales procedit, numquam fidei revera adversabitur, quia res pofanae et res fidei ab eodem Deo originem decunt", Constitutio pastoralis de Ecclesia in mundo humus tempore, w: La Chiesa nel mondo contemporaneo. Commento alla Costituzione pastorale „, Gaudium et spes”, red. E. Giammancheri, Brescia 1966, s. 414.

${ }^{41}$ Congregazione per L'Educazione Cattolici. Pontificio Consilio per Laici. PontifiCio Consiglio della Cultura, Presenza della Chiesa nell'università e nella cultura universitaria, II, 2, w: EV 14, 1349-1405.

42 Jan Pawel II, Przemówienie wygloszone z okazji sześćsetlecia Wydziału Teologicznego Uniwersytetu Jagiellońskiego, s. 744.
} 
„utylitarną”, ze szkodą dla formacji humanistycznej i nie uwzględnia głębszych potrzeb osoby.

Dostrzegając to poważne zachwianie tożsamości uniwersytetu Jan Paweł II apelował, by uniwersytety nie zapominały o misji wychowawczej, ale starały się ją gorliwie pełnić w służbie nowych pokoleń, odwołując się do dziedzictwa ideałów i wartości, które cechowały uniwersytety w minionych wiekach. Już w pierwszych uniwersytetach, jak np. w tym w Paryżu, który mieścił się w specjalnie wydzielonej części miasta, należącej do studentów i kolegiów, zwanej universitas, istniał nie tylko zespolony ośrodek studiów, miasteczko uniwersyteckie, ale były stworzone warunki do spotykania się ludzi zajmujących się nauką, studiami ${ }^{43}$. I choć, jak pisze Le Goff, w XIV w. profesorowie uniwersytetów nie byli wolni od chciwości w pobieraniu opłat od studentów za naukę i opowiadali się nawet za wyznaczeniem przepisów określających, jakie podarki winni składać im studenci przy egzaminach, uniwersytety $\mathrm{w}$ średniowieczu przyjmowały i kształciły pewną liczbę ubogich studentów nieodpłatnie ${ }^{44}$.

Model uniwersytetu, jaki w Niemczech w początkach XIX w. zaproponował Wilhelm Humboldt nie akcentował wartości wspólnoty i jej roli w formacji a poprzestawał raczej na kształtowaniu samodzielnego, myślącego, krytycznego akademika, który będzie czuł się odpowiedzialny za określoną dziedzinę życia społeczeństwa i za dobro państwa ${ }^{45}$. Humboldt postrzegał religię jedynie w kategoriach funkcjonalno-moralnych i inspirował się głównie kulturą antyczną i ideałami oświecenia.

Na uwagę zasługuje nieco późniejszy model uniwersytetu autorstwa Johna Henry'ego Newmana sporządzony w związku z otwarciem Katolickiego Uniwersytetu Irlandzkiego, którego tenże uczony oksfordzki został pierwszym rektorem w 1852 r. Według niego, uniwersytet jest „miejscem nauczania uniwersalnej wiedzy, co z jednej strony oznacza cel intelektualny, a nie moralny tej instytucji, z drugiej zaś raczej komunikowanie i szerzenie wiedzy, niż jej postęp”46. „Komunikowanie wiedzy” dokonuje się w określonym miejscu i poprzez osobiste kontakty z innymi, spotkania. Zakres studiów winien zawierać przedmioty obejmujące tę wiedzę, która jest potrzebna studentom.

${ }^{43}$ G. D’onofrio, Historia teologii, II, Epoka średniowieczna, tłum. W. Szymona, Kraków 2010, s. 308

${ }^{44}$ J. LE GofF, Inteligencja w wiekach średnich, tłum. E. Bąkowska, Warszawa 1997, s. 118.

${ }^{45}$ F.G. FRIMEL, Eine Universität für Erfurt?, w: Von Gott reden in skularer Gesellschaft, red. E. Coreth i in., Erfurt 1996, s. 349; W. von Humboldt, Schrifften zur Anthropologie und Bildungslehre, Dusseldorf-München 1956, s. 27-32; 71.

${ }^{46}$ J.H. Newman, Idea Uniwersytetu, Przedmowa, thum. P. Mroczkowski, Warszawa 1990, s. 79. 
„Wszechnica" to miejsce nauczania, zgromadzenie uczonych nie tylko rywalizujących ze sobą i zabiegających o rozwój swoich nauk, dyscyplin, ale i obcujących ze sobą, zżytych ze sobą, uzgadniających ważne twierdzenia naukowe i relacje między ich dziedzinami badań, starających się o zachowanie między sobą intelektualnego pokoju ${ }^{47}$. Ową „czystą, jasną atmosferą myślową" tworzonej i podtrzymywanej tradycji uniwersyteckiej oddychają studenci przyswajając sobie gruntownie wybrane przedmioty. Przekaz wiedzy dokonuje się w uniwersytecie nie tylko na linii uczony-student, ale i pośród samych studentów różnych kierunków, gdy otwierają się oni na „wielkie kontury wiedzy” i wkomponowują w „całość” społeczności akademickiej. ,[...] kiedy masa młodych ludzi pełnych zapału, o otwartych oczach i sercach, przyjaznych w stosunku do otoczenia [...] zejdzie się w jednym miejscu i swobodnie ze sobą obcuje, można być pewnym, że będą się uczyć jedni od drugich, nawet jeśli by nie było nikogo, kto ma ich nauczać; rozmowa wszystkich jest serią wykładów dla każdego z osobna, zdobywają sobie nowe idee i poglądy, świeży materiał do przemyśleń i określone zasady wypowiadania sądów i działania, dzień po dniu"48. Spotkanie, jako czynnik przynależący do istoty funkcjonowania uniwersytetu, może ujawnić zgodność poglądów albo rozbieżność i to, co najważniejsze - wspólne dążenie do poznania prawdy. Newman rozpatruje uniwersytet w swojej wewnętrznej istocie i w powiązaniu z Kościołem. Twierdzi, że jeśli jakiś uniwersytet staje się katolicki, to w dalszym ciągu „wychowanie intelektualne” pozostaje podstawowym jego zadaniem, a Kościół wywiera na nie „stabilizujący wpływ”. Uważa, że jest on „niezbędny dla integralności uniwersytetu”49.

Odwołując się do dziedzictwa ideałów i wartości przeszłości, aby je ożywić dla aktualnej realizacji misji uniwersytetu Jan Paweł II kilkakrotnie cytuje Newmana i jego filozofię edukacji, z której wiele myśli i wskazań, pomimo upływu stu pięćdziesięciu lat, uznaje za cenne. Peter Stravinskas uważa nawet, że konstytucja Ex Corde Ecclesiae jest „przepełniona myślą i duchem Johna Henry'ego Newmana" ${ }^{50}$. Aby zapobiec liberalnej technokratycznej i redukcjonistycznej tendencji, dostrzegalnej w wielu uniwersytetach, zagrażającej uniwersytetom katolickim Papież we wzmiankowanej konstytucji pisze, że uniwersytet winien „tworzyć autentyczną ludzką wspólnotę ożywianą duchem Chrystusa. Źródłem jedności jej członków jest wspólne

\footnotetext{
${ }^{47}$ Tamże, V, 1.

48 Tamże, VI, 9

${ }^{49}$ Tamże, Przedmowa.

${ }^{50}$ P. STRAVInSKas, Ex Corde Ecclesiae - echo Newmanowskiej idei uniwersytetu, w: Jaka tożsamość uniwersytetu? „Człowiek w Kulturze” 21(2009-2010), s. 18.
} 
poświęcenie się prawdzie, jedna wizja godności człowieka - i w ostatecznej analizie - Osoba i orędzie Chrystusa, który nadaje instytucji uniwersytetu szczególny charakter" ${ }^{\prime \prime}$. Z trzech wartości jednoczących osoby w uniwersytecie katolickim Papież wymienia najpierw prawdę, która jest wartością jednoczącą naukowców i studentów każdego uniwersytetu i zapewniającą obiektywizm badań naukowych. Następnie wymienia ,jedną wizję godności człowieka", której dostarcza teologia odczytując objawienie Boże w duchu wierności tradycji Kościoła i jego Magisterium oraz ukazując zasady Ewangelii. „Osoba i orędzie Chrystusa” zostaje wymieniona jako czynnik jedności na trzecim miejscu najprawdopodobniej dlatego, by uniknąć zarzutu podnoszonego przez środowiska laickie, że „chrześcijańskość”, katolickość” przesłania „uniwersyteckość” oraz podejrzeń o konfesyjność w myśleniu naukowym $^{52}$. Chrystus „,nadaje instytucji uniwersytetu katolickiego szczególny charakter", wyrażający się w tym, że: a) tak jednostki, jak cała społeczność tego uniwersytetu kierują się chrześcijańską inspiracją; b) refleksja w nim prowadzona podejmowana jest w świetle wiary katolickiej nad „dziedzictwem ludzkiej wiedzy", do której uniwersytet katolicki wnosi swój wkład; c) nauczający i studenci starają się być wierni chrześcijańskiemu orędziu, które Kościół przekazuje; d) uniwersytet jako instytucja służy aktywnie ludowi Bożemu i ludzkości ukazując chrześcijański sens życia i jego transcendentny cel, tj. Boga ${ }^{53}$.

Nauczyciele uniwersyteccy tworzą wspólnotę na dwa sposoby: 1) doskonaląc własne kwalifikacje naukowe i prowadząc badania zgodnie z wymogami merytorycznymi i formalnymi właściwych im dyscyplin oraz ukazując wyniki swych poszukiwań „w kontekście spójnej wizji świata”. Podstawowym wyznacznikiem tej wizji, a także istotnym kryterium wszystkich programów, które pozwalają ją urzeczywistnić, jest dobro człowieka - osoby we wspólnocie. To natomiast, co owo dobro umniejsza lub redukuje do rzeczy, czyni środkiem do czegoś innego itp., niszczy wizję antropologiczną i uniemożliwia realizację świata bardziej ludzkiego; 2) bycie świadkami i pedagogami takiego kształtu życia chrześcijańskiego, w którym uwidacznia się dwojaka integracja: a) wiary z kulturą, zwłaszcza z tą jej postacią, w którą każdy nauczyciel jest najbardziej zaangażowany; b) „kompetencji zawodowej z chrześcijańską mądrością" zmierzającą do tego, by postęp wiedzy

\footnotetext{
${ }^{51}$ JAN PAWEL II, Ex Corde Ecclesiae, 21.

52 S. SAWICKI, Uniwersytet katolicki: koncepcja i zarys pewnego modelu, „Summarium” 41(61) 2012, s. 19-20.

53 Jan Pawel II, Ex Corde Ecclesiae, 13.
} 
i technologii służył życiu ludzkiemu, realizacji sprawiedliwości i utrwaleniu pokoju na świecie ${ }^{54}$.

„Zadaniem studentów jest zdobywanie wykształcenia, które harmonijnie łączy wysoki poziom kultury humanistycznej ze specjalistyczną wiedzą zawodową”. W wykształceniu Papież akcentuje najpierw wartość „,wysokiego poziomu kultury humanistycznej”, która powinna ich skłaniać do „poszukiwania prawdy i jej sensu w ciągu całego życia"55. Już Ojcowie Soboru Watykańskiego II stwierdzili, że należy tak kształtować ducha, aby rozwijała się zdolność podziwiania, wnikania w głąb kontemplacji i urabiania sobie sądu osobistego oraz zdolność kształcenia zmysłu religijnego, moralnego i społecznego" (GS 59). To istotne dla wychowania wskazanie było podyktowane dostrzegalną już wówczas antynomią pomiędzy postępem nauk i umiejętności technicznych a ,zachowaniem w ludziach zdolności do kontemplacji i podziwu, które prowadzą do mądrości”, antynomią rodzącą pytania o sposób uzgodnienia „nowej”, technicznej kultury z kulturą duchową tak, by kultura ludzka „urabiała całą osobę ludzką i pomagała ludziom wypełnić ich zadania" w świecie dzisiaj (GS 56). Sama kultura techniczna, dająca człowiekowi władzę nad światem od zewnątrz, nie jest w stanie „urobić” całej osoby ludzkiej, gdyż nie ukształtuje jej serca, sumienia i nie odpowie na jej wielkie egzystencjalne pytania, choć może ją mocno pociągać i zachwycać swymi wynalazkami i ich praktycznym zastosowaniem. Świadom tej tendencji Jan Paweł II mówił o „błędzie antropologicznym”, czyli o „błędnym pojmowaniu człowieka i zawartych w nim dynamizmów" 56 i definiowaniu go bez uwzględniania wszystkich tworzących go czynników i płaszczyzn realizacji człowieczeństwa. Celem przezwyciężenia go w wykształceniu uniwersyteckim większego znaczenia winny nabrać takie nauki humanistyczne, jak teologia, filozofia, psychologia, socjologia oraz nauki humanistyczne o profilu filologicznym i historycznym, gdyż wnoszą one wiele w wyjaśnienie tego, czym jest człowiek, a zwłaszcza teologia, która jest nauką o człowieku $\mathrm{w}$ aspekcie zbawienia $\mathrm{i} \mathrm{w}$ świetle wiary poszukującej rozumienia wszystkiego, w tym także życia ludzkiego, głębszego sensu pracy itp. Pomaga ona

\footnotetext{
54 Tamże, 22.

55 Tamże, 23.

${ }^{56}$ „U podstaw tych wszystkich form nieprawdy leży błędne pojęcie człowieka i zawartych w nim dynamizmów. $Z$ tej błędnej rzeczywistości formy te czerpią pokarm dla siebie i z kolei one same ją zasilają. Pierwsze kłamstwo i zasadniczy fałsz to niewiara w człowieka, w człowieka z całym potencjałem jego wielkości, niewiara w konieczność Odkupienia człowieka od zła i grzechu, który jest w nim", Jan PaweŁ II, Prawda siła pokoju. Orędzie na XIII Światowy Dzień Pokoju, 1 I 1980, OsRom, 1-2(1980), s. 3.
} 
usytuować specjalistyczne przygotowanie zawodowe na tle humanistycznym i religijnym.

„Ukształtowaniu naukowemu studentów powinno towarzyszyć dogłębne wykształcenie moralne i chrześcijańskie" - mówił Papież do katolickiego świata naukowego w Meksyku, zachęcając profesorów i studentów do realizacji ,harmonijnej syntezy wiary i umysłu, wiary i kultury, wiary i życia. Owa synteza - twierdził - musi dokonywać się nie tylko na poziomie badań i wykształcenia, lecz także na poziomie wychowczo-pedagogicznym" ${ }^{57}$. Uzyskiwaniu bardziej egzystencjalnego kształtu tej syntezy służą nie tylko wykłady, ale i duszpasterstwo uniwersyteckie. Konstytucja Ex Corde Ecclesiae uznaje je za niezastąpioną formę działalności uniwersytetu będącą konkretną realizacją misji Kościoła na jego terenie „umożliwiającą członkom społeczności uniwersyteckiej skoordynowanie studiów i innego rodzaju

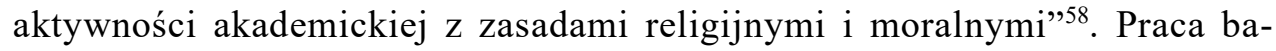
dawcza, okupiona osobistym wysiłkiem profesora, wykłady wprowadzające studentów w tajemnice myślenia naukowego i wychowanie akademickie człowieka łączą się w jednym trójrytmie i stanowią o życiu uniwersytetu i o takich jego wartościach wychowawczych, jak rzetelna praca, trud, odpowiedzialność ${ }^{59}$. W tych wartościach ludzkich, intelektualnych uczestniczą studenci jako ci, którzy są wychowywani.

Czym jest wychowanie? Pojęcie wychowania człowieka zakłada dwie podstawowe prawdy o człowieku i naturze jego urzeczywistnienia. Pierwszą jest ta, że „człowiek jest powołany do życia w prawdzie i miłości”, a drugą, że urzeczywistnia się on przez bezinteresowny dar z samego siebie (GS 24). Przyjmując je Papież określa wychowanie procesem, w którym dochodzi do głosu komunia osób w szczególny sposób i w którym wychowawca „rodzi” drugą osobę w znaczeniu duchowym i ludzkim ${ }^{60}$. Celem wychowania jest to, aby człowiek stawał się coraz bardziej człowiekiem, aby bardziej „był”, a nie tylko więcej „miał”; aby przez to wszystko, co „ma”, co „posiada”, umiał bardziej i pełniej być człowiekiem. Inaczej mówiąc, aby również umiał bardziej być nie tylko „z drugimi”, ale także i „dla drugich”61. Tak rozumiane wychowanie zakłada integralną wizję człowieka i domaga się

\footnotetext{
${ }^{57}$ Jan PaWę II, Dokonać syntezy wiary $i$ kultury, w: TenżE, Wiara $i$ kultura, s. 16.

${ }^{58} \mathrm{Nr} 38$.

${ }^{59}$ M.A. KrĄPIEC, Człowiek. Kultura. Uniwersytet, wybór i oprac. A. Wawrzyniak, Lublin 1982, s. 373.

${ }^{60}$ JAN PAWEE II, List Gratissimam sanae, 16.

${ }^{61}$ JaN PAWEe II, $W$ imię przyszłości kultury, Przemówienie $w$ UNESCO. Paryż, 2 czerwca 1980, w: TENŻE, Wiara i kultura, s. 58.
} 
uwzględnienia jego podmiotowości, godności i praw. W wychowaniu chrześcijańskim istotne jest doprowadzenie człowieka do osobistej relacji z Chrystusem i głębokiego udziału w Jego życiu ${ }^{62}$, co dokonuje się przez otwarcie się wychowanka na światło Ducha Świętego udzielane w medytacji słowa Bożego i wprowadzenie go w misterium odkupienia uobecniane w liturgii Kościoła, zwłaszcza w Eucharystii. Chrystus, objawiając człowiekowi człowieka w pełni, ukazuje mu „najwyższe jego powołanie” (GS 22).

Środowiskiem wychowującym do wiary jest najpierw rodzina, w której kształtują się pierwsze postawy ludzkie i duchowe dziecka. Drugą jest parafia - będąca wspólnotą wiernych przyjmującą człowieka do siebie, zwłaszcza podczas Eucharystii. W niej, a także w obrębie określonej diecezji, funkcjonują w sposób formalny czy nieformalny małe wspólnoty religijne mające duże znaczenie $\mathrm{w}$ wychowaniu $\mathrm{w}$ wierze dzieci i młodzieży. Także rolę szkoły, w której ma miejsce katecheza i uniwersytetu katolickiego ze wszystkimi jego wymienionymi możliwościami należy postrzegać jako wspomagającą wychowanie rozpoczęte $\mathrm{w}$ rodzinie $\mathrm{i}$ przeradzające się $\mathrm{z}$ czasem w samowychowanie. Obowiązkiem państwa jest stworzenie takiego systemu oświaty, który respektuje wartości moralne i religijne narodu i przekonania religijne jego obywateli ${ }^{63}$. Również władze kościelne winny chronić praw i wolności uniwersytetu wobec społeczeństwa cywilnego i udzielać mu materialnego wsparcia, jeśli takie jest konieczne.

Studenci winni dążyć do połączenia swej specjalizacji z określonej dziedziny wiedzy z formacją religijno-moralną, z przeżywaną wiarą i z tym, do czego ona zobowiązuje w życiu. Odkrycie i przeżywanie powołania chrześcijańskiego we wspólnocie akademickiej, jako wspólnocie wiary, stanowi możliwość nawiązania komunii z innymi w Chrystusie i zrozumienia swojej misji w Kościele i w świecie. Dojrzałość duchowa polega na zasymilowaniu całej rzeczywistości Wcielenia i Odkupienia i dzięki temu na „odnalezieniu siebie" ${ }^{64}$. Dojrzałość ludzka polega na pełnym użyciu daru wolności i poświęceniu się w duchu miłości i służby innym. Jedna i druga zakłada zdolność rozeznania prawdziwego dobra człowieka w świetle wiary, wolę naśladowania Jezusa Chrystusa i zdolność czerpania z Niego mocy Ducha do zachowania własnej wolności. Zakłada ona także to, co Wojtyła określał uczestnictwem w wymiarze międzyludzkim i społecznym, czyli uczestnictwo

\footnotetext{
62 JaN PAWE⿺ II, Encyklika Redemptor hominis, 10.

${ }^{63}$ Jan Pawel II, Orędzie na XIV Światowy Dzień Pokoju (8 XII 1980), OsRom 11(1980), s. 3.

${ }^{64}$ JaN PaWeŁ II, Redemptor hominis, 10.
} 
w człowieczeństwie bliźniego (,,ja”-,ty”) i w dobru wspólnym („,my”) ${ }^{65}$. Uczestnictwo w człowieczeństwie bliźniego polega na budowaniu wspólnoty podmiotowej a nie jedynie przedmiotowej, np. wypełnianie z innymi jakiegoś zadania. Uczestnictwo w sensie społecznym oznacza przyjmowanie i realizowanie tej części, jaka komuś przypada z racji przynależności do określonej wspólnoty i spełnianie się osoby przez relację do dobra wspólnego. Oznacza ono nie tylko postawę solidarności z innymi w pomnażanym dobru, ale, jeśli zachodzi konieczność moralna, także sprzeciw wobec niewłaściwych postaw innych we wspólnocie i poza nią ${ }^{66}$. Wymienione dwa wymiary uczestnictwa winny zostać zintegrowane $\mathrm{z}$ formacją intelektualną, duchową i ludzką otrzymaną we wspólnocie akademickiej uniwersytetu katolickiego. Bardzo pomocne w tym względzie jest duszpasterstwo akademickie przygotowujące studentów do aktywnego uczestnictwa w życiu Kościoła ${ }^{67}$. Wprawdzie wiara, przeżywana we wspólnocie akademickiej, nie daje człowiekowi monopolu na ucieleśnienie poszczególnych wartości ludzkich, intelektualnych i nie pokazuje w jaki sposób należy je ucieleśnić, ukazuje jednak młodemu człowiekowi globalną perspektywę sensu życia i w niej je zakorzenia, oraz pobudza go do zaangażowania przez czerpanie sił od Ducha Świętego ${ }^{68}$.

Obok zgłębiania i przeżywania powołania chrześcijańskiego, młody człowiek winien rozeznać także własne życiowe powołanie, tj. powołanie do małżeństwa albo do życia konsekrowanego czy kapłańskiego. Studia jako specjalistyczne przygotowanie do podjęcia określonej pracy a następnie sama praca, pracowitość „warunkują cały proces wychowania” w tym sensie, że człowiek przez pracę staje się bardziej człowiekiem ${ }^{69}$. Praca „warunkuje życie i utrzymanie rodziny”, a więc umożliwia realizację życiowego powołania.

\section{MISJA UNIWERSYTETU KATOLICKIEGO W KOŚCIELE I W ŚWIECIE}

Uniwersytet katolicki nie może zachować swej tożsamości inaczej, jak tylko zachowując więź z Kościołem nie tylko lokalnym, ale i powszechnym.

\footnotetext{
${ }^{65} \mathrm{~K}$. WojtyŁa, Osoba i czyn oraz inne studia antropologiczne, red. T. Styczeń i in., Lublin 1994, s. 309.

${ }^{66}$ P. TARASIEWICZ, Uczestnictwo jako podstawa życia spolecznego wedtug Karola Wojtyly, w: Wokót antropologii Karola Wojtyły (Zadania współczesnej metafizyki, 18), red. A. Maryniarczyk $\mathrm{i}$ in., Lublin 2016, s. 418-424.

${ }^{67}$ Jan PaWel II, Ex Corde Ecclesiae, 41.

${ }^{68}$ M. FALISE, L'Université et l'éducation aux valeurs, „Nouvelle Revue Théologique” 117 (1995), s. 15.

${ }^{69}$ JAN PAWEL II, Encyklika Laborem exercens, 10.
} 
Ta więź jest istotna i z racji zewnętrznych, instytucjonalnych i, jeszcze bardziej, z racji wierności, uznawania autorytetu nauczycielskiego Kościoła oraz konieczności stosowania się do jego wskazań w sprawach wiary i moralności ${ }^{70}$.

Konstytucja Ex Corde Ecclesiae powołując się na przysługującą kulturze, a w jej ramach - nauce, „należytą wolność” i „prawowitą możność samodzielnego działania wedle własnych zasad" w granicach wyznaczonych przez wymogi prawdy i dobra wspólnego (GS 59), stwierdza, że „Kościół [...] uznaje także akademicką wolność poszczególnych badaczy we właściwej dziedzinie ich kompetencji" 71 . Odnosi się to do wszystkich naukowców, w tym także do teologów i uprawianej przez nich dyscypliny, która posiadając własne zasady i metody cieszy się statusem nauki. Instrukcja Kongregacji Nauki Wiary o powołaniu teologa w Kościele mówi wprost o „misji teologa w Kościele" 72 wpisującej się w misję uniwersytetu. Istotnym elementem misji Kościoła jest odczytywanie w Duchu Świętym prawdy zbawczej zawartej w słowie Bożym i przekazywania jej ludziom celem ożywiania ich wiary. Z tą misją utożsamiają się zwłaszcza teologowie, których zadaniem jest uzyskiwanie, w łączności z Urzędem Nauczycielskim Kościoła coraz głębszego rozumienia słowa Bożego - zawartego w judeochrześcijańskim objawieniu i przekazanego przez Tradycję Kościoła - i udostępnianie go Ludowi Bożemu ${ }^{73}$ i tym wszystkim, którzy poszukują prawdy ewangelicznej, aby przyjmując ją i żyjąc według niej, mogli dostąpić zbawienia $(1 \mathrm{Tm} 2,4)$. Przenikając sens objawienia rozświetlony światłem wiary i dociekaniem rozumowym teolog, zanim przekaże wyniki swych badań Ludowi Bożemu, ku jego zbudowaniu, winien je obiektywizować w braterskiej dyskusji z innymi teologami i, w przypadku, gdy prawda okaże się inna, czy też gdy Magisterium Kościoła zgłosi zastrzeżenia, być gotowy do modyfikacji własnych opinii ${ }^{74}$ tak, by pozostać wiernym doktrynie katolickiej.

Teologowie winni uwzględniać aktualną sytuację Kościoła w świecie i różne problemy i wyzwania, jakie niesie ze sobą współczesna kultura. Uniwersytet katolicki nie może nie dostrzegać zmian, pozytywnych i negatywnych, jakie dzieją się aktualnie w kulturze i nie ustosunkować się do nich pozostając w pewnej alienacji wobec swego otoczenia, społeczeństwa, narodu.

${ }^{70}$ Jan Pawel II, Ex Corde Ecclesiae, 27.

71 Tamże, 29.

${ }^{72} \mathrm{Nr}$ 2, w: W trosce o petnię wiary. Dokumenty Kongregacji Nauki Wiary 1966-1994, thum. Z. Zimowski, J. Królikowski, Tarnów 1995, s. 354.

73 Tamże, II, 6-7.

${ }^{74}$ Tamże, II, 11. 
Uniwersytet - według Jana Pawła II - ,jest otwarty na całość ludzkiego doświadczenia, zawsze gotów do dialogu i nauczenia się czegoś od każdej kultury. W proces ten uniwersytet katolicki wnosi bogate doświadczenie kulturowe Kościoła. Zachowując ponadto świadomość, że kultura ludzka jest otwarta na Objawienie i transcendencję, uniwersytet katolicki odgrywa pierwszoplanową i uprzywilejowaną rolę w owocnym dialogu między Ewangelią a kulturą"75.

Według Jana Pawła II, kultura jest „właściwością człowieka” w tym sensie, że „wyodrębnia go spośród wszystkich innych istot”, że wywodzi się od niego i istnieje dla niego ${ }^{76}$. Kultura wywodzi się od człowieka w tym sensie, że człowiek, otrzymawszy pewne zdolności, może je rozwijać z pożytkiem dla siebie i dla innych tworząc kulturę, gdy np. uprawia wiedzę, pracuje nad udoskonaleniem warunków życia i kondycji własnej i innych oraz nad zdobywaniem pełniejszej prawdy o świecie, o naturze w relacji do Boga, Prawdy najwyższej. Jest on także ,adresatem kultury”, gdyż kultura ma za cel „realizację osoby we wszystkich jej wymiarach, wraz ze wszystkimi jej zdolnościami. Za pierwszorzędny przedmiot kultury uznaje Papież „rozwój człowieka jako człowieka, człowieka jako osoby, czyli - człowieka jako jedynego i niepowtarzalnego osobnika w rodzinie ludzkiej" ${ }^{77}$. Co może wnieść w rozwój tak rozumianej kultury uniwersytet katolicki?

Wnosi zaakcentowanie w kulturze tego, co ludzkie - humanum. „Istnieje tylko jedna kultura, kultura człowieka, tworzona przez człowieka i dla człowieka”, pisze Papież i odnośnie do roli uniwersytetu w Kościele stwierdza za Pawłem VI: „Kościół zaś, znawca spraw ludzkich, posługując się swymi uniwersytetami katolickimi, korzystając z ich dziedzictwa humanistycznego i naukowego, zgłębia tajemnicę człowieka i świata, ujaśniając je w blasku Objawienia” ${ }^{78}$. Człowiek jest także „tajemnicą”, którą można wyjaśniać w jakimś stopniu w świetle objawienia, w świetle tajemnicy Słowa wcielonego (GS 22). „W duchu swoistego uniwersalnego humanizmu - dopowiada Papież - uniwersytet katolicki oddaje się całkowicie zgłębianiu wszystkich aspektów prawdy w ich istotowej jedności z Prawdą najwyższą, którą jest Bóg"79, z czego wynika, że zadaniem katolickich instytucji nauczania wyższego

\footnotetext{
${ }^{75}$ Ex Corde Ecclesiae, 43.

${ }^{76}$ JAN PAWE⿺ II, Kultura służy wyniesieniu człowieka i rozwojowi wspótpracy między narodami. Przemówienie do intelektualistów, Coimbra, 15 maja 1982, w: TENŻE, Wiara i kultura, s. 139.

${ }^{78}$ PaweŁ VI, Przemówienie w ONZ (4 października 1965), w: Insegnamenti di Paolo VI, t. III (1965), s. 508; JAN PAWEe II, Ex Corde Ecclesiae, 3.

${ }^{79}$ Jan PaWel II, Ex Corde Ecclesiae, 4.
} 
„jest zgłębiać odważnie bogactwa Objawienia i bogactwa natury, tak by połączony wysiłek rozumu i wiary pozwolił ludziom osiągnąc pełnię własnego człowieczeństwa" ${ }^{80}$. Uniwersytet jest więc miejscem zgłębiania owych dwóch źródeł poznania nie tylko w sposób teoretyczny, ale i egzystencjalny we wspólnocie z innymi i w ramach odbywanej formacji intelektualnej, duchowej i ludzkiej ukierunkowanej na „osiągnięcie pełni własnego człowieczeństwa", czyli doprowadzenia możliwości działania do optimum potentiae, do najwyższego stopnia ${ }^{81}$. Taka odnowa i rozwój człowieka są możliwe do uzyskania nie własną mocą, ale przez otwarcie się na Ducha Świętego i przez współpracę z Nim. Duch Święty poprzez swe dary, a zwłaszcza dar mądrości prowadzi człowieka do połączenia w jedną życiową syntezę wiedzę, aktywność zawodową i inne podejmowane przedsięwzięcia z dobrami religijnymi. Mądrość to poznanie i działanie ze świadomością ostatecznego celu, wiedza i działania szczegółowe to organizowanie środków i posługiwanie się nimi, aby ów cel osiągnąć. Uniwersytet jako wspólnota ożywiana - dzięki duszpasterstwu akademickiemu - duchem wiary, staje się źródłem kultury, gdyż relacje międzyludzkie są $\mathrm{w}$ niej odnawiane według „logiki” communio ${ }^{82}$, a związek Ewangelii przyjmowanej wiarą z człowiekiem i z tym co on czyni, motywowany moralnością chrześcijańską, jest kulturotwórczy ${ }^{83}$.

Jeśli uniwersytet katolicki będzie skutecznym narzędziem postępu kulturowego tak jednostek, jak i całej społeczności, będzie mógł wypełnić swą służbę względem Kościoła, którego misją jest nieść światu zbawienie i odnawiać ludzkie społeczeństwo (GS 3). Kościół wypełni lepiej ową misję duchową, jeśli uniwersytet katolicki, przez swe badania naukowe, pomoże mu zrozumieć ważniejsze problemy współczesne, jak godność życia ludzkiego, dążenie do sprawiedliwości dla wszystkich, jakość życia osobistego i rodzinnego, ochrona środowiska naturalnego, poszukiwanie pokoju i bezpieczeństwa, bardziej równomierny podział zasobów świata i budowanie bardziej ludzkiego porządku gospodarczego i politycznego na płaszczyźnie krajowej i międzynarodowej ${ }^{84}$.

Jeśli w odnowie i w budowaniu właściwego porządku społecznego wystąpią poważne przeszkody moralne, uczestnictwo uniwersytetu w życiu

\footnotetext{
${ }^{80}$ Tamże, 5.

${ }^{81}$ I. ChŁodna-BŁACH, Od paidéi do kultury wysokiej. Filozoficzno-antropologiczne podstawy sporu o kulturze, Lublin, 2016, s. 200.

${ }^{82}$ E. CORECCO, La Chiesa luogo di cultura. La Chiesa e le sue università, „Nuovo Areopago” 4(1988), s. 37.

${ }^{83}$ JAN PAWEe II, W imię przyszłości kultury, w: TeNŻE, Wiara i kultura, s. 57.

${ }^{84}$ Jan PAWEL II, Ex Corde Ecclesiae, 32.
} 
społecznym, pełnione $\mathrm{w}$ duchu misji chrześcijańskiej, winno wyrażać się także w sprzeciwie wobec niesprawiedliwych układów i struktur społecznych i w głoszeniu prawdy niewygodnej, służącej obronie autentycznego dobra społeczeństwa. $Z$ tej racji, według papieża, należy najpierw badać i oceniać w duchu chrześcijańskim normy i wartości dominujące we współczesnym społeczeństwie i kulturze, a także przekazywać społeczeństwu zasady etyczne i religijne nadające sens życiu ludzkiemu. Polecana jest tu bardzo współpraca między różnymi dyscyplinami akademickimi uniwersytetu, każda bowiem z nich może wnieść swój własny wkład w badania i w rozwiązywanie złożonych problemów społecznych oraz w rozwój i postęp społeczeństwa. Niejednokrotnie istnieje potrzeba łączenia w tym celu wysiłków różnych uniwersytetów.

Istotną kwestią w badaniach naukowych jest „troska o etyczny wymiar nauki”, zwłaszcza fizyki, chemii, biologii i genetyki, ale także i nauk społecznych. Doceniając wielkie osiągnięcia nauki i technologii Papież niejednokrotnie uświadamiał naukowcom ich wielką odpowiedzialność wobec społeczeństwa i ludzkości. „Nie wszystko to, co jest możliwe do wykonania w wymiarze materialnym, jest też moralnie godziwe, gdyż nie wszystko pozostaje w harmonii z godnością i wartością człowieka - mówił do rektorów uniwersytetów. [...] Nie samą techniką żyje człowiek. $Z$ tej racji staje się dzisiaj bardziej żywe, również $w$ akademickich gronach Europy i świata, przekonanie, że uniwersytety ponoszą specyficzną odpowiedzialność za stymulowanie refleksji dotyczącej etycznego aspektu badań teoretycznych i stosowanych, oraz że nowe technologie mogą prowadzić do powstania konfliktów etycznych prawnych o niezwykłym znaczeniu dla codziennego życia" ${ }^{85}$. Działalność naukowa, badawcza nigdy nie jest neutralna wobec człowieka, lecz zawsze przynosi albo dobroczynny, albo negatywny skutek, dlatego też powinna być prowadzona nie tylko w sposób prawdziwie naukowy, ale także z poszanowaniem norm moralnych (por. GS 36). Tylko wówczas człowiek nie będzie się lękał, że jego wytwory zostaną użyte przeciw niemu, ale że będą podporządkowane jego obiektywnemu dobru i słusznym interesom ludzkości.

Uniwersytet katolicki, jako ośrodek kształcenia, pobudza różne formy aktywności kulturowej i podejmuje dialog służący poznawaniu różnych kultur, ich wartości i, ewentualnie, ich negatywnych aspektów. Dzięki temu staje się

85 JAN PAWE€ II, Przemówienie na forum rektorów uniwersytetów europejskich. Rzym, 19 kwietnia 1991, w: S. SowiŃSKI, R. ZENDEROwSKi, Europa droga Kościoła. Jan Pawet II o Europie i europejskości, s. 248. 
niezwykle przydatny już na przedpolu ewangelizacji prowadzonej przez Kościół, gdyż ta zakłada potrzebę uprzedniego „zrozumienia i krytycznego przeniknięcia poszczególnych tożsamości kulturowych"86. Ewangelizacja wymaga wychodzenia Kościoła ku kulturom i inkulturacji Ewangelii dokonanej w taki sposób, by przeniknęła ona dogłębnie owe kultury i by „przewracała kryteria oceny, hierarchię dóbr, postawy i nawyki myślowe, bodźce postępowania i modele życiowe rodzaju ludzkiego, które stoją w sprzeczności ze słowem Bożym i planem zbawczym" "87. Nie ma ona nigdy na celu zniszczenia cennych dla danej kultury wartości, ale jedynie ich „oczyszczenie”, „podniesienie” i „uzupełnienie” w Chrystusie (GS 58).

W realizacji tego zadania mogą pomóc ,uniwersytety katolickie, które z natury swej dążą do tego, by realizować 'publiczną, stałą i powszechną obecność myśli chrześcijańskiej w całym dążeniu do rozwoju wyższej kultury'(GE 10)" ${ }^{88}$. Ewangelizacja dzisiaj nie jest rozumiana jako tylko niesienie Ewangelii ad gentes, ale także jako kształtowanie duchowych wspólnot w różnych środowiskach i kulturach zobojętniałych religijnie, zsekularyzowanych, w których istnieje potrzeba „odtworzenia chrześcijańskiej tkanki społeczności ludzkiej" (ChL 34). Dokonuje się ona także w zwykłym duszpasterstwie, które winno uwzględniać czynnik i kontekst kulturowy. Jana Pawła II nauka o ewangelizacji kultur streszcza się w: 1) zaakcentowaniu transcendencji objawienia Bożego w stosunku do kultur, Ewangelia bowiem przerasta je, choć zarazem potrzebuje w nich zakorzenienia na podobieństwo wcielenia Syna Bożego, które było „wcieleniem kulturowym”; 2) oparciu jej na koncepcji antropologicznej inspirowanej myślą chrześcijańską z epoki Ojców Kościoła, sprowadzającej się do przekonania, że kultura, gdy jest poprawna, „objawia i umacnia naturę człowieka" ${ }^{89}$. Aby móc rozpoznać wartości w jakiejś kulturze potrzebny jest dialog prowadzony z różnymi kulturami dzisiejszego świata i tradycjami kulturowymi. Identyfikując w nich takie wartości antropologiczne, jak pozytywny stosunek do osoby ludzkiej, do jej wolności i godności, poczucie odpowiedzialności oraz otwartość na transcendencję, uniwersytet katolicki może pomóc zintegrować je z dziełem ewangelizacji i z rozwojem osób, społeczeństw i narodów.

\footnotetext{
86 Międzynarodowa Komisja Teologiczna, Wiara i inkulturacja (1988), 7, (http://www. vatican.va/roman_curia/congregations/cfaith/cti_docume...[17. 08.2019]), s. 2.

${ }^{87}$ PAWEe VI, Adhortacja Evangelii nuntiandi, 19.

88 Jan PAwEl II, Sapientia Christiana, 2.

${ }^{89}$ Międzynarodowa Komisja TeOlogiczna, Wiara i inkulturacja (1988), 6 -7.
} 


\section{ZAKOŃCZENIE}

Z przeprowadzonej analizy misji uniwersytetu katolickiego, dokonanej na podstawie Konstytucji Ex Corde Ecclesiae i przemówień Jana Pawła II do świata uniwersyteckiego, Kościoła i świata kultury, nasuwają się następujące spostrzeżenia i wnioski:

1. Przesłanie Jana Pawła II było podyktowane troską o zapobieżenie postępującej degradacji misji uniwersytetu w świecie współczesnym, a zwłaszcza w społeczeństwach zglobalizowanych, w których lansowany jest utylitarystyczny model uniwersytetu uzależniony od praw społecznej i ekonomicznej ewolucji tych społeczeństw.

2. Szczególnie misja uniwersytetów katolickich, powołanych z natury do łączenia w swej działalności dwóch porządków: poszukiwania prawdy o świecie i człowieku z wiarą odwołującą się do objawienia prawdy najwyższej, jest aktualna i ważna w kulturze współczesnej, w której bardzo potrzebne jest świadectwo wierności podstawowym wartościom uniwersytetu.

3. Model uniwersytetu katolickiego, ukazywany przez Jana Pawła II, nacechowany jest troską o prawdę we wszystkich dziedzinach wiedzy, jej poszukiwanie, odkrywanie i głoszenie. Nie ogranicza się on do prawdy o świecie i człowieku ukazywanej przez nauki matematyczno-przyrodnicze, techniczne, co jest typowe dla pozytywistycznego modelu uniwersytetu, ale uwzględnia pełną prawdę o człowieku i świecie ukazywaną zwłaszcza przez nauki humanistyczne oraz filozofię i teologię. Papież wzywa do urzeczywistniania tego modelu uniwersytetu dzisiaj przez zgłębianie zarówno bogactwa objawienia, jak i natury, czyli przez zaangażowanie się w badania naukowe i dydaktykę rozumem i wiarą tak, by poznana prawda o człowieku i naturze była owocem współdziałania rozumu i wiary.

4. W tej perspektywie badawczej i poznawczej należy dążyć do integracji wiedzy z obiektywnym dobrem człowieka i społeczeństwa i nie tracić z oczu etycznego wymiaru nauki. Poznaniu i urzeczywistnieniu obiektywnego dobra człowieka i społeczeństwa służy jedność profesorów i studentów oparta na prawdzie, jednej wizji godności człowieka i na wartościach chrześcijańskich. Kształtuje się ona w wymiarze duchowym i ludzkim przez intelektualną, moralno-duchową i ludzką formację w uniwersytecie i w jego środowisku - wspieranym przez duszpasterstwo akademickie - i ma na celu budowanie autentycznej wspólnoty, w której każdy może uzyskiwać coraz większą dojrzałość i przygotować się do urzeczywistnienia przypadającego mu powołania w Kościele i w świecie. Powołanie to obejmuje zarówno udział w ewangelizacji kultury jak i budowanie kultury i cywilizacji godnej człowieka. 


\section{BIBLIOGRAFIA}

Augustyn, Wyznania, X, 23, tłum. Z. Kubiak, Instytut Wydawniczy PAX, Warszawa 1992.

ChŁodnA-BŁACH I., Od paidéi do kultury wysokiej. Filozoficzno-antropologiczne podstawy sporu o kulturze, Wydawnictwo KUL, Lublin, 2016.

Congregazione Per L'educazione Cattolici. Pontificio Consilio Per Laici. Pontificio Consilio Della Cultura, Presenza della Chiesa nell'università e nella cultura universitaria, II, 2, w: EV 14, 1349-1405.

Corecco E., La Chiesa luogo di cultura. La Chiesa e le sue università, „Nuovo Areopago” 4(1988), s. 22-40.

D’onofrio G., Historia teologii, II, Epoka średniowieczna, tłum. W. Szymona, Wydawnictwo M, Kraków 2010.

FALisE M., L'Université et l'éducation aux valeurs, „Nouvelle Revue Théologique” 117(1995), s. 3-18.

Frimel F.G., Eine Universität für Erfurt?, w: Von Gott reden in skularer Gesellschaft, red. E. Coreth i in., Benno Verlag, Erfurt 1996, s. 347-356.

GiLson E., Uniwersytety i scholastyka, w: Zrozumieć Średniowiecze, wybór i oprac. R. Mazurkiewicz, Wydawnictwo Diecezji Tarnowskiej BIBLOS, Tarnów 1997, s. 222-227.

GoFf LE J., Inteligencja $w$ wiekach średnich, tłum. E. Bąkowska, Oficyna Wydawnicza Volumen, Warszawa 1997.

GURRIDO J.J., Misja chrześcijanina w czasach kryzysu kultury, w: Postmodernizm, „Communio. Międzynarodowy Przegląd Teologiczny" 14(1994), 6, s. 68-101.

Humboldt W. v., Schrifften zur Anthropologie und Bildungslehre, Verlag Helmud Küpper, Dusseldorf-München 1956.

JAN PAWEe II, Encyklika Fides et ratio o relacjach między wiara a rozumem, Pallottinum, Poznań 1998.

Jan PaWeŁ II, Encyklika Laborem exercens, Pallottinum, Poznań 1981.

JAN PAWE⿺ II, Konstytucja apostolska Ex Corde Ecclesiae o uniwersytetach katolickich (15 kwietnia 1979), 1, w: Tenże, Dzieła zebrane, t. IV, Wydawnictwo M, Kraków 2007, s. 86-104.

JAN PAWE⿺ II, Konstytucja apostolska Sapientia christiana o uniwersytetach $i$ wydziałach katolickich (15 sierpnia 1990), w: TenżE, Dzieła zebrane, t. IV, Wydawnictwo M, Kraków 2007, s. 15-31.

Jan Pawet II, List do Rodzin Gratissimam sanae (2. luty 1994), w: Posoborowe dokumenty Kościoła Katolickiego o matżeństwie i rodzinie, t. II, wybór i wstęp K. Lubowicki, Wydawnictwo M, Kraków 1999, s. 33-103.

Jan PaweŁ II, Orędzie na XIV Światowy Dzień Pokoju (8 XII 1980), OsRom 11(1980) s. 3-4.

Jan PaweŁ II, Prawda siła pokoju. Orędzie na XIII Światowy Dzień Pokoju, 1 I 1980, OsRom 1-2 (1980), s. 3-4.

JAN PAWEe II, Przemówienie na forum rektorów uniwersytetów europejskich, Rzym, 19 kwietnia 1991, w: S. SowiŃSKI, R. Zenderowski, Europa droga Kościoła. Jan Pawet II o Europie i europejskości, Zakład Narodowy im. Ossolińskich, Wrocław 2003, s. 244-249.

JAN PAWEŁ II, Silmy się dobrze myśleć. Spotkanie z przedstawicielami świata nauki i kultury. Triest 2 V 1992, OsRom 7(1992), s. 14-16. 
JAN PAwEe II, Wiara i kultura, oprac. M. Radwan SCJ i in., Redakcja Wydawnictw KUL, Rzym-Lublin 1988.

Kongregacja NAUKi Wiary, Instrukcja o powolaniu teologa w Kościele „Donum veritatis”, w: W trosce o petnię wiary. Dokumenty Kongregacji Nauki Wiary 1966-1994, thum. Z. Zimowski, J. Królikowski, Wydawnictwo Diecezji Tarnowskiej BIBLOS, Tarnów 1995, s. 353-369.

KrĄPIEC M.A., Człowiek. Kultura. Uniwersytet, wybór i oprac. A, Wawrzyniak, Redakcja Wydawnictw KUL, Lublin 1982.

La Chiesa nel mondo contemporaneo. Commento alla Costituzione pastorale „Gaudium et spes”, red. E. Giammancheri, Queriniana, Brescia 1966.

LAMBert D., Ryzykowne spotkanie teologii z nauka, thum. P. Korycińska, Copernicus Center Press, Kraków 2018.

MięDzynarodowa Komisja Teologiczna, Wiara i inkulturacja (1988), (http://www.vatican.va/ roman_curia/congregations/cfaith/cti_docume... [17.08.2019]).

Newman J.H., Idea Uniwersytetu, tłum. P. Mroczkowski, Państwowe Wydawnictwo Naukowe, Warszawa 1990.

ОкоŃSKA E., Uniwersytet jako szkoła dialogu w społeczeństwie obywatelskim, „Studia Bydgoskie" 1(2007), s. 155-165.

Ozorowski E., Nauka a pytania graniczne, „Rocznik Teologii Katolickiej” 7(2007), s. 7-10.

PAwEe VI, Adhortacja Evangelii nuntiandi, Wrocław 2001.

PAWEL VI, Insegnamenti di Paolo VI, t. III (1965).

SAWICKI S., Uniwersytet katolicki: koncepcja i zarys pewnego modelu, „Summarium” 41(61) 2012, s. $19-32$

Stravinskas P., Ex Corde Ecclesiae - echo Newmanowskiej idei uniwersytetu, w: Jaka tożsamość uniwersytetu? „Człowiek w Kulturze” 21(2009-2010), s. 17-33.

TARASIEWICZ P., Uczestnictwo jako podstawa życia spolecznego wedtug Karola Wojtyly, w: Wokót antropologii Karola Wojtyły (Zadania współczesnej metafizyki, 18), red. A. Maryniarczyk i in., Polskie Towarzystwo Tomasza z Akwinu, Lublin 2016, s. 417-432.

Wielgus S., O nowym paradygmacie uniwersytetu z okazji inanguracji osiemdziesiatego roku akademickiego w Katolickim Uniwersytecie Lubelskim, „Przegląd Uniwersytecki”. Dodatek Specjalny, Katolicki Uniwersytet Lubelski, Lublin 1997, s. 5-20.

WojtYŁA K., Osoba i czyn oraz inne studia antropologiczne, red. T. Styczeń i in., TN KUL, Lublin 1994.

WojtYŁA K., Wykłady lubelskie. Człowiek i moralność, 3, red. T. Styczeń i in., TN KUL, Lublin 1986.

ŻYCIŃSKI J., Inspiracje chrześcijańskie w powstaniu nauki nowożytnej, Redakcja Wydawnictw KUL, Lublin 2000.

\section{DUCHOWA MISJA UNIWERSYTETU WEDŁUG ŚW. JANA PAWŁA II}

\section{STRESZCZENIE}

Uniwersytet jako ,jedyny w swoim rodzaju ośrodek twórczej pracy i promieniowania wiedzy, służący dobru ludzkości”, choć wyrasta z tradycji ukształtowanej przez Kościół, we współ- 
czesnych społeczeństwach zglobalizowanych znajduje się w kryzysie, gdyż został w dużej mierze uzależniony od myślenia utylitarystycznego i od czynników merkantylistycznych i przekształcony w model służący interesom społecznej i ekonomicznej ewolucji tych społeczeństw. Artykuł jest próbą całościowego określenia misji uniwersytetu katolickiego na podstawie Konstytucji Ex Corde Ecclesiae Jana Pawła II oraz jego przemówień do świata uniwersyteckiego i środowisk kultury. Misja ta polega na: 1) poszukiwaniu „całej prawdy o naturze, o człowieku i o Bogu” odwołując się do wiary i rozumu i ich zdolności czerpania prawdy z dwóch źródeł: objawienia i rzeczywistości stworzonej; 2) tworzeniu wspólnoty opartej na prawdzie, jednej wizji godności człowieka, wartościach chrześcijańskich oraz wychowaniu do dojrzałości chrześcijańskiej i ludzkiej; 3) przygotowaniu studentów do urzeczywistnienia przypadającego im w Kościele i w świecie powołania obejmującego zarówno udział w ewangelizacji kultur jak i budowanie kultury i cywilizacji godnej człowieka.

Słowa kluczowe: Uniwersytet katolicki; misja; prawda; człowiek; wspólnota; ewangelizacja; dobro społeczeństwa. 